\title{
Differential gene expression profiles of invasive and non-invasive non-functioning pituitary adenomas based on microarray analysis
}

\author{
Françoise Galland $^{1,2 *}$, Ludovic Lacroix ${ }^{3,4 *}$, Patrick Saulnier ${ }^{3}$, \\ Philippe Dessen ${ }^{4,5}$, Geri Meduri ${ }^{1,9,10}$, Michèle Bernier ${ }^{7}$, Stéphane Gaillard ${ }^{8}$, \\ Jean Guibourdenche $e^{2,6}$, Thierry Fournier ${ }^{2}$, Danièle Evain-Brion ${ }^{1,2}$, \\ Jean Michel Bidart ${ }^{3,4}$ and Philippe Chanson , $^{1,9}, 10$
}

\footnotetext{
${ }^{1}$ Assistance Publique-Hôpitaux de Paris, Hôpital de Bicêtre, Service d'Endocrinologie et des Maladies de la Reproduction, Le Kremlin-Bicêtre F-94275, France

${ }^{2}$ Institut National de la Santé et de la Recherche Médicale, Unité 767, Faculté des Sciences Pharmaceutiques et Biologiques, Université René Descartes, Paris F-75006, France

${ }^{3}$ Institut de Cancérologie Gustave-Roussy, Laboratoire de Recherche Translationnelle, Villejuif F-94805, France

${ }^{4}$ Centre National de la Recherche Scientifique, FRE 2939, Institut de Cancérologie Gustave-Roussy and Université Paris-Sud 11, Villejuif F-94805, France

${ }^{5}$ Département de Génomique Fonctionnelle, Villejuif F-94805, France

${ }^{6}$ Assistance Publique-Hôpitaux de Paris, Hôpital Cochin, Service de Biochimie, Paris F-75014, France

${ }^{7}$ Hôpital Foch, Service d'Anatomopathologie, Suresnes F-92151, France

${ }^{8}$ Service de Neurochirurgie, Suresnes F-92151, France

${ }^{9}$ Institut National de la Santé et de la Recherche Médicale, Unité 693, Le Kremlin-Bicêtre F-94276, France

${ }^{10}$ Université Paris-Sud 11, Faculté de Médecine Paris-Sud, Unité Mixte de Recherche-S693, Le Kremlin-Bicêtre F-94276, France
}

(Correspondence should be addressed to $\mathrm{P}$ Chanson at Hôpital de Bicêtre, Service d'Endocrinologie et des Maladies de la Reproduction, 78 rue du Général Leclerc, Le Kremlin-Bicêtre, F-94275, France; Email: philippe.chanson@bct.aphp.fr)

*(F Galland and L Lacroix contributed equally to this work)

\begin{abstract}
Non-functioning pituitary adenomas (NFPAs) may be locally invasive. Markers of invasiveness are needed to guide patient management and particularly the use of adjuvant radiotherapy. To examine whether invasive NFPAs display a specific gene expression profile relative to non-invasive tumors, we selected 40 NFPAs (38 of the gonadotroph type) and classified them as invasive $(n=22)$ or non-invasive $(n=18)$ on the basis of magnetic resonance imaging and surgical findings. We then performed pangenomic analysis with the 44k Agilent human whole genome expression oligonucleotide microarray in order to identify genes with differential expression between invasive and non-invasive NFPAs. Candidate genes were then tested in qRT-PCR. Prediction class analysis showed that the expression of 346 genes differed between invasive and non-invasive NFPAs $(P<0.001)$, of which 233 genes were up-regulated and 113 genes were down-regulated in invasive tumors. On the basis of Ingenuity networks and the degree of up- or down-regulation in invasive versus non-invasive tumors, 35 genes were selected for expression quantification by qRT-PCR. Overexpression of only four genes was confirmed, namely IGFBP5 $(P=0.02)$, MYO5A $(P=0.04), F L T 3(P=0.01)$, and NFE2L1 $(P=0.02)$. At the protein level, only myosin 5A (MYO5A) immunostaining was stronger in invasive than in non-invasive NFPAs. Molecular signature allows to differentiate 'grossly' invasive from non-invasive NFPAs. The product of one of these genes, MYO5A, may be a useful marker of tumor invasiveness.
\end{abstract}

Endocrine-Related Cancer (2010) 17 361-371 


\section{Introduction}

Pituitary adenomas represent at least $10 \%$ of intracranial neoplasms (Melmed 2003, Ezzat et al. 2004). Non-functioning pituitary adenomas (NFPAs) are distinguished from functioning forms on the basis of clinical and biochemical features. Most NFPAs are gonadotroph adenomas expressing steroidogenic factor 1 (Asa et al. 1996, Al-Shraim \& Asa 2006), required for differentiation of gonadotroph cells, and producing follicle-stimulating hormone (FSH) $\beta$ and/or luteinizing hormone (LH) $\beta$ and/or $\alpha$-subunit. Although classified as slow-growing benign brain tumors, $\sim 40 \%$ of NFPAs show characteristics of local invasion: they erode the sella turcica and spread into neighboring tissues, invading the sphenoid bone inferiorly and the cavernous sinus laterally. Total surgical removal may be impossible, owing to the risk of damaging vital vascular or nervous structures. Recurrences may develop from tumor remnants, necessitating additional surgery or radiation, with a risk of further complications. The potential for proliferation and for invasion may be totally independent: some huge tumors remain enclosed, while some microadenomas are locally invasive. Generally, preoperative imaging and/or peroperative findings show whether or not a pituitary adenoma is invasive. However, equivocal cases require long-term surveillance, and adjuvant treatment may be delayed. There is thus a need for markers of invasiveness based on surgical specimens.

Numerous genetic alterations may play a role in pituitary tumorigenesis (Ezzat et al. 1995, 2002, Zhang et al. 1999, 2002, 2003, Pagotto et al. 2000, Evans et al. 2001, 2003, Korbonits et al. 2002, Simpson et al. 2002, Heaney et al. 2003, Bahar et al. 2004, Emery et al. 2006, Leontiou et al. 2008), but few data are available on the molecular factors underlying the invasiveness of sporadic pituitary adenomas, and particularly NFPAs. The role of PTTG (Zhang et al. 1999, Salehi et al. 2008) and the N-terminally truncated isoform of fibroblast growth factor receptor 4 (FGFR4) (ptd-FGFR4; Qian et al. 2004) has been suggested. Overexpression of polysialylated neural cell adhesion molecule has been related to pituitary adenoma invasion (Trouillas et al. 2003), and overexpression of matrix metalloproteases (MMPs), and particularly MMP-9, has been detected in various types of invasive adenoma (Turner et al. 2000, Gong et al. 2008, Hussaini et al. 2007). Bone morphogenic protein, a factor involved in gonadotroph tumor development, might also play a role along with retinoic acid-inducible neural-specific protein 3 (Shorts-Cary et al. 2007).

Here, we investigated whether invasive NFPAs display a specific gene expression profile relative to non-invasive tumors. We used microarrays to analyze 40 NFPAs (mainly gonadotroph tumors), of which 22 NFPAs were invasive and 18 NFPAs were non-invasive. The aim was to find a specific expression profile for invasive tumors, in order to guide therapeutic decision making and particularly the use of adjuvant radiotherapy.

\section{Materials and methods}

\section{NFPA tumors and tissue characterization}

Forty pituitary NFPA specimens were obtained after transsphenoidal surgery. The patients were managed in our center at Bicêtre Hospital, and relevant clinical and hormonal findings, preoperative imaging studies, immunohistochemical findings, and post-operative outcome were available. Tissue portions not used for histology were frozen at $-80{ }^{\circ} \mathrm{C}$ in isopentane and stored in liquid nitrogen directly after surgical resection, pending RNA extraction. Gonadotroph tumors were further characterized by immunostaining for FSH $\beta$ and LH $\beta$ and/or $\alpha$-subunit. Tumor size and invasiveness were defined on the basis of preoperative magnetic resonance imaging (MRI) and perioperative findings, using the modified Hardy criteria (Hardy 1979), as follows: grade I, enclosed microadenoma (tumor $<10 \mathrm{~mm}$ ); grade II, enclosed macroadenoma (tumor $>10 \mathrm{~mm}$ ); grade III, localized perforation of the sellar floor; and grade IV, diffuse destruction of the sellar floor. The site of extrasellar extension was designated by a letter as follows: suprasellar extension $(\mathrm{O}, \mathrm{A}, \mathrm{B}$, or $\mathrm{C})$ with $\mathrm{O}$ : none, A: occupies the suprasellar cistern, B: recesses of the third ventricle obliterated, C: grossly displaced third ventricle; parasellar extension (D and $\mathrm{E}$ ) with $\mathrm{D}$ : intracranial (intradural) and E: into or beneath the cavernous sinus (extradural). Grade III and IV tumors were considered invasive. Tumor invasion was based on evidence of bone destruction and/or tumor extension within the sphenoid and/or cavernous sinuses and/or brain, as confirmed at surgery. The longest anterior-posterior, vertical, and transverse diameters were measured, and tumor volume was calculated as $0.5 \times$ width $\times$ length $\times$ height (Lundin \& Pedersen 1992). After surgery, all the patients were periodically reassessed clinically and radiologically to check for signs and symptoms of disease recurrence. Tumor recurrence was diagnosed if radiological signs of regrowth of a tumor remnant or a new tumor were found (in patients with no surgical remnants). Remnant tumors were considered stable if there was no evidence of growth on two MRI within 1 year interval and no signs of disease reactivation. 
On this basis, there were 22 invasive and 18 noninvasive NFPAs, and all but one of the NFPAs were macroadenomas. The clinical and morphological characteristics of these tumors are summarized in Table 1. This series and an independent series of 19 NFPAs (all of gonadotroph type), 10 invasive and 9 non-invasive followed at our department in Bicêtre Hospital, were used to validate the set of genes differentially expressed from microarray analysis. The protocol was approved by the Review Board of our institution, and the patients gave their informed consent.

\section{Total RNA extraction}

Total RNA was isolated from frozen tissue by using Trireagent (Sigma-Aldrich), and was purified on RNeasy columns (Qiagen) according to the manufacturer's protocols. RNA quality, based on the 28S:18S ribosomal RNA ratio, was assessed with an Agilent bioanalyzer (Agilent Technologies, Palo Alto, CA, USA). All specimens included in this study had a ratio higher than 1.5. RNA samples were frozen in nuclease-free water until use (Promega Corporation).

Table 1 Clinical and pathological characteristics of 40 non-functioning pituitary adenomas

\begin{tabular}{|c|c|c|c|c|c|c|}
\hline $\begin{array}{l}\text { Pituitary } \\
\text { adenomas } \\
\text { (PA) number }\end{array}$ & $\begin{array}{c}\text { Age at } \\
\text { surgery } \\
\text { (years)/sex }\end{array}$ & $\begin{array}{l}\text { Hormonal } \\
\text { secretion }\end{array}$ & $\begin{array}{l}\text { Immunohisto- } \\
\text { chemistry }\end{array}$ & $\begin{array}{c}\text { Tumor } \\
\text { volume }\left(\mathrm{cm}^{3}\right)\end{array}$ & $\begin{array}{l}\text { Tumor } \\
\text { grading } \\
\text { (Hardy) }\end{array}$ & $\begin{array}{l}\text { Follow-up time } \\
\text { from surgery } \\
\text { (years)/outcome }\end{array}$ \\
\hline PA01 & $61 / \mathrm{M}$ & NF & $\mathrm{FSH} \beta$ & 10.0 & IV, C, D, E & 4.5/recurrence \\
\hline PA02 & $58 / \mathrm{M}$ & NF & $\mathrm{FSH} \beta, \mathrm{LH} \beta$, and $\alpha \mathrm{SU}$ & 2.2 & II, B, E & 4.5/recurrence \\
\hline PA03 & $74 / \mathrm{M}$ & NF & $\mathrm{LH} \beta$ and $\alpha \mathrm{SU}$ & 77.0 & IV, C, D, E & 3.5/stably remnant \\
\hline PA04 & $75 / \mathrm{M}$ & NF & $\mathrm{LH} \beta$ and $\mathrm{FSH} \beta$ & 7.8 & III, B & 4/stably remnant \\
\hline PA05 & $51 / \mathrm{M}$ & NF & $\mathrm{LH} \beta$ and $\mathrm{FSH} \beta$ & 33.3 & IV & 4/stably remnant \\
\hline PA06 & $54 / \mathrm{M}$ & NF & $\mathrm{LH} \beta, \mathrm{FSH} \beta$, and $\alpha \mathrm{SU}$ & 21.4 & IV, C & 4/stably remnant \\
\hline PA07 & $71 / \mathrm{M}$ & NF & $\mathrm{FSH} \beta$ & 4.0 & IV & 4/stably remnant \\
\hline PA08 & $90 / \mathrm{M}$ & NF & $\mathrm{FSH} \beta$ and $\alpha \mathrm{SU}$ & 4.0 & IV, B, E & $2.5 /$ stably remnant \\
\hline PA09 & $77 / \mathrm{M}$ & NF & $\mathrm{LH} \beta$ and $\mathrm{FSH} \beta$ & 4.0 & IV, B, E & 3.5/stably remnant \\
\hline PA10 & 83/M & NF & $\mathrm{LH} \beta, \mathrm{FSH} \beta$, and $\alpha \mathrm{SU}$ & 10.5 & IV, C, E & 3.5/stably remnant \\
\hline PA11 & $70 / \mathrm{M}$ & NF & $\mathrm{LH} \beta, \mathrm{FSH} \beta$, and $\alpha \mathrm{SU}$ & 2.9 & III, B, E & 3.5/stably remnant \\
\hline PA12 & $73 / F$ & NF & $\mathrm{LH} \beta$ & 13.5 & IV, B, E & 3.5/stably remnant \\
\hline PA13 & $52 / \mathrm{M}$ & NF & $\mathrm{FSH} \beta$ & 7.8 & IV, B, E & 3/stably remnant \\
\hline PA14 & $59 / F$ & $\mathrm{FSH}$ & $\mathrm{FSH} \beta$ & 7.8 & IV, B, E & $5.5 /$ recurrence \\
\hline PA15 & $59 / F$ & NF & $\mathrm{FSH} \beta$ & 7.8 & III, B, E & 3/remnant \\
\hline PA16 & $76 / \mathrm{M}$ & NF & $\mathrm{FSH} \beta$ & 7.8 & IV, B, E & 3/remnant \\
\hline PA17 & $48 / \mathrm{M}$ & NF & $\mathrm{FSH} \beta$ & 7.8 & III, C, E & 3/remnant \\
\hline PA18 & $63 / \mathrm{M}$ & NF & $\mathrm{LH} \beta$ and $\mathrm{FSH} \beta$ & 13.5 & IV, B, E & 3/remnant \\
\hline PA19 & $74 / F$ & NF & $\mathrm{LH} \beta, \mathrm{FSH} \beta$, and $\alpha \mathrm{SU}$ & 6.9 & IV, B, E & 3/remnant \\
\hline PA20 & $47 / M$ & $\mathrm{FSH}$ & $\mathrm{LH} \beta, \mathrm{FSH} \beta$, and $\alpha \mathrm{SU}$ & 2.1 & IV, B, E & 2.5/remnant \\
\hline PA25 & $70 / \mathrm{M}$ & NF & $\mathrm{LH} \beta$ and $\mathrm{FSH} \beta$ & 7.4 & III, A & $9.5 /$ recurrence inv \\
\hline РА30 & $60 / \mathrm{M}$ & NF & $\alpha \mathrm{SU}$ & 7.8 & III, B & 4/recurrence inv \\
\hline PA21 & $67 / \mathrm{M}$ & NF & $\alpha S U$ & 2.9 & $\mathrm{II}, \mathrm{O}$ & $6.5 /$ no remnant \\
\hline PA22 & $82 / \mathrm{M}$ & NF & $\mathrm{LH} \beta$ and $\alpha \mathrm{SU}$ & 9.4 & II, B & $6.5 /$ no remnant \\
\hline PA23 & $68 / F$ & NF & Negative & 6.5 & II, B & $6.5 /$ no remnant \\
\hline PA24 & $60 / F$ & NF & $\mathrm{FSH} \beta$ & 3.5 & II, C & $6.5 /$ no remnant \\
\hline PA26 & $43 / \mathrm{M}$ & $\mathrm{FSH}$ & $\mathrm{FSH} \beta$ & 9.2 & II, O & $10.5 /$ stably remnant \\
\hline PA27 & $37 / F$ & NF & $\mathrm{LH} \beta, \mathrm{FSH} \beta$, and $\alpha \mathrm{SU}$ & 1.6 & II, A & 3.5/stably remnant \\
\hline PA28 & $35 / F$ & $\mathrm{FSH}, \mathrm{LH}$ & $\mathrm{LH} \beta$ and $\mathrm{FSH} \beta$ & 1.7 & II & 4/no remnant \\
\hline PA29 & $56 / \mathrm{M}$ & NF & $\mathrm{LH} \beta$ & 4.0 & II, B & $4 /$ no remnant \\
\hline PA31 & $42 / F$ & NF & $\mathrm{LH} \beta$ and $\mathrm{FSH} \beta$ & 0.5 & 1 & 4/no remnant \\
\hline PA32 & 82/M & NF & $\mathrm{LH} \beta$ and $\mathrm{FSH} \beta$ & 4.0 & II, B & $4 /$ no remnant \\
\hline PA33 & $64 / F$ & NF & $\mathrm{FSH} \beta$ & 4.0 & II, B & 4/no remnant \\
\hline PA34 & $63 / F$ & NF & Negative & 7.8 & II, C & 4/no remnant \\
\hline PA35 & $55 / \mathrm{M}$ & NF & $\mathrm{FSH} \beta$ & 2.5 & II, B & 4/no remnant \\
\hline PA36 & $56 / F$ & NF & $\mathrm{LH} \beta, \mathrm{FSH} \beta$, and $\alpha \mathrm{SU}$ & 7.8 & II, B & $4 /$ no remnant \\
\hline PA37 & $51 / \mathrm{M}$ & NF & $\mathrm{LH} \beta$ and $\mathrm{FSH} \beta$ & 10.2 & II, B & 4/no remnant \\
\hline PA38 & $51 / \mathrm{M}$ & NF & $\mathrm{LH} \beta, \mathrm{FSH} \beta$, and $\alpha \mathrm{SU}$ & 4.0 & II, B & 4/no remnant \\
\hline PA39 & $55 / \mathrm{M}$ & NF & $\mathrm{FSH} \beta$ & 4.3 & II, A & 3.5/stably remnant \\
\hline PA40 & $30 / F$ & NF & $\mathrm{LH} \beta$ and $\mathrm{FSH} \beta$ & 8.0 & II, B & $3 /$ no remnant \\
\hline
\end{tabular}

$\mathrm{PA}$, pituitary adenoma; NF, non-functioning; $\alpha \mathrm{SU}, \alpha$-subunit. 


\section{Microarray hybridization}

Microarray analysis was performed with Agilent competitive hybridization of each sample versus a common reference. Because the reference sample should prefererentially have an expression profile that resembles that of the test samples, we used reference as a pool of equal amounts of total RNA from all samples (Knapen et al. 2009). Five microgram aliquots of total RNA from each sample and from the reference pool were used to generate labeled antisense cRNAs with T7 RNA polymerase. We used Agilent customdesigned 60-mer oligonucleotide microarrays and dual-color analysis in which probes from all samples and from the reference RNA are labeled with cyanine 5-CTP and cyanine 3-CTP respectively. These microarrays had 44000 features representing the whole genome (44K Agilent Human Genome, Agilent Technologies). Reverse transcription, linear amplification, cRNA labeling, and purification were performed with the Agilent Linear Amplification kit. Hybridization was allowed to proceed for $17 \mathrm{~h}$ at $60{ }^{\circ} \mathrm{C}$, with $1 \mu \mathrm{g}$ of cyanine 5-labeled cRNA from each tumor mixed with the same amount of cyanine 3-labeled cRNA from the reference pool. The arrays were then washed with $0.6 \times$ and $0.01 \times$ SSC buffers containing Triton, and were dried with a nitrogen gun before scanning with an Agilent DNA microarray scanner. The fluorescence images thus obtained were quantified with Feature Extraction software (Agilent Technologies). All the microarray data have been submitted to Array Express at the European Bioinformatics Institute (http://www.ebi.ac.uk/arrayexpress/). Array Express is a public repository for microarray data, created to store well-annotated data in accordance with microarray gene expression data recommendations (http://www.mged.org).

\section{Reverse transcription and quantitative real-time PCR analysis}

Reverse transcription was performed using $1 \mu \mathrm{g}$ total RNA from each sample in a reaction volume of $20 \mu \mathrm{l}$ containing $50 \mathrm{U}$ Moloney murine leukemia virus reverse transcriptase, $20 \mathrm{U}$ ribonuclease inhibitor (Applied Biosystems, Foster City, CA, USA), $1 \mathrm{mmol} / \mathrm{l}$ dNTPs (Amersham Pharmacia Biotech), $5 \mathrm{mmol} / \mathrm{l} \mathrm{MgCl}_{2}, 10 \mathrm{mmol} / \mathrm{l}$ Tris- $\mathrm{HCl}$ (pH 8.3), $10 \mathrm{mmol} / \mathrm{l} \mathrm{KCl}$, and $50 \mathrm{pmol} / \mathrm{l}$ random hexamers (Perkin Helmer Corp PE Applied Biosystems). A subset of 35 genes was tested by quantitative real-time PCR (qRT-PCR). Oligonucleotide primers and Taqman probes specific for each gene were designed to be intron spanning using PrimerExpress software
(Applied Biosystems; Supplementary Table 1, see section on supplementary data given at the end of this article). Sequences were obtained from the GenBank database, and the oligonucleotides were purchased from MWG Biotech (Courtaboeuf, France). Primers and probes for other specific genes and housekeeping genes were obtained from Assays-On-Demand (Applied Biosystems; Supplementary Table 1). Quantitative RT-PCR used TaqMan Universal PCR Master Mix and was run on an ABI PRISM 7700 sequence detection system (Applied Biosystems). Each reaction was performed with cDNA equivalent to $20 \mathrm{ng}$ total RNA per tube in a final volume of $20 \mu \mathrm{l}$, and the expression of each target gene was determined simultaneously for all samples in 96-well plates. Each target gene was normalized to the human acidic ribosomal phosphoprotein $\mathrm{PO}$ gene RPLPO. Gene expression values were calculated with the $2^{-\Delta \Delta \mathrm{C}_{\mathrm{t}}}$ method, where the $\Delta C_{\mathrm{t}}$ value of the sample was determined by subtracting the average $C_{\mathrm{t}}$ value of the target gene from the average $C_{\mathrm{t}}$ value of the RPLPO gene. The reference pool, corresponding to the microarray reference RNA, was used as calibrator $(1 \times$ sample $)$.

\section{Immunohistochemical analysis}

Formalin-fixed paraffin-embedded pituitary tumor samples (five invasive and six non-invasive) selected from among those used for microarrays were studied by immunohistochemistry, along with two necropsy samples of normal anterior pituitary tissue. Fivemicron-thick tissue sections were deparaffinized, rehydrated, and microwaved in pH6 citrate buffer at $100^{\circ} \mathrm{C}$ for $15 \mathrm{~min}$. After a wash in PBS and $15 \mathrm{~min}$ of preincubation with a commercial serum-free protein block (Dako, Carpinteria, CA, USA), the sections were incubated overnight at $4{ }^{\circ} \mathrm{C}$ in a humid chamber with the following primary antibodies: rabbit anti-human insulin-like growth factor binding protein 5 (IGFBP5) (GroPep Ltd, Adelaide, SA, Australia; dilution: $0.04 \mu \mathrm{g} / \mathrm{ml}$ ), which does not cross-react with other IGFBP isoforms; rabbit anti-myosin 5A (MYO5A; GeneTex, Inc., Irvine, CA, USA; dilution: 1/300); monoclonal anti-pituitary tumor transforming gene (PTTG) (Novocastra Laboratories; dilution 1/50); monoclonal anti-Ki67 (Dako; dilution 1/100); and monoclonal antihuman p53 (Dako; dilution: 1/50). Pre-immune rabbit and mouse immunoglobulin at the appropriate dilutions were applied as negative controls to serial sections of each sample. Bound antibodies were revealed with a commercial peroxidase-labeled streptavidin immunohistochemical kit (LSAB 2, Dako), according to the manufacturer's instructions. 
Aminoethylcarbazole was used as chromogen. Finally, some sections were counterstained with Meyers hematoxylin and mounted in aqueous medium (Glycergel, Dako). Protein expression was scored blindly by two observers using a conventional optical microscope (Provis, Olympus, Tokyo, Japan). A score was calculated as the percentage of immunostained tumor cytoplasm (for IGFBP5 and MYO5A) or nuclei (Ki67 and p53) in the most representative field $(\times 400)$. Immunostaining intensity was scored as negative $(-)$; weak $(+/-)$; moderate $(+)$; or strong $(++)$. Several sections of each tumor were examined, and the highest score was used for statistical analysis.

\section{Bioinformatics and statistical analysis}

All data were filtered to eliminate low-intensity values using a threshold (under 100 arbitrary units for both colors) based on the linearity test. Genes showing minimal variation across the set of arrays were excluded from further analysis. To select only genes with differential expression, we applied a 1.5-fold change cutoff, before any other statistical analysis, as previously used in our group (Raslova et al. 2007). We focused on gene showing a difference in expression of at least 1.5 -fold from the median in at least $20 \%$ of the arrays. Genes significantly different between the classes, with $P$ values of at least 0.001 , were used for class prediction to discriminate between invasive and non-invasive tumors. Bioinformatic analysis of microarray data was performed with BrB-ArrayTools version 3.7. This model was developed to identify gene expression profiles predicting the class of future samples. The models are based on the Compound Covariate Predictor (Radmacher et al. 2002), Diagonal Linear Discriminant Analysis (Dudoit et al. 2002), Nearest Neighbor Classification (Dudoit et al. 2002), and Support Vector Machines with linear kernel (Ramaswamy et al. 2001). The models incorporated genes that were differentially expressed among genes at the 0.001 significance level, as assessed with the random variance $t$-test (Wright \& Simon 2003). We estimated the prediction error of each model by leave-one-out cross-validation (LOOCV) as described by Radmacher et al. (Simon et al. 2003). For each LOOCV training set, the entire model-building process was repeated, including the gene selection process. We also examined whether the cross-validated error rate estimate for a given model was significantly less than would be expected from random prediction. The class labels were randomly permuted, and the entire LOOCV process was repeated. The significance level is the proportion of random permutations that gave a cross-validated error rate no greater than the cross-validated error rate obtained with the real data. One thousand random permutations were used.

The class prediction dataset was analyzed by using Ingenuity Pathway Analysis software (www.ingenuity. com). A dataset containing gene identifiers and their corresponding expression values, such as fold changes and $P$ values, was uploaded as a tab-delimited text file. Each gene identifier was mapped to its corresponding gene object in the Ingenuity Pathways Knowledge Base. A 1.5-fold change cutoff and a $P$ value of $<0.001$ were used to identify genes with differential expression. These genes, called 'focus genes', were then used as the starting point to generate biological networks.

Unpaired $t$-tests with Welch's correction (Prism 4, Graphpad Software, Inc., San Diego, CA, USA) were applied to qRT-PCR data for invasive and non-invasive NFPAs. $P$ values below 0.05 were considered to denote significant differences.

\section{Results}

\section{Clinical and morphological characteristics}

The patients consisted of 27 men and 13 women, aged from 30 to 90 years. Mean age was 66 and 55 years in the invasive and non-invasive subgroups respectively $(P=0.02$; Table 1$)$. All the patients had biochemically NFPAs, except for four patients who had above normal serum levels of FSH $(n=3)$ or both FSH and LH $(n=1)$. All but two tumors showed positive immunostaining for $\mathrm{FSH} \beta, \mathrm{LH} \beta$, and/or $\alpha$-subunit. On imaging, the volume of invasive and non-invasive tumors was not significantly different $(P=0.07)$. Maximal tumor volume before surgery ranged from 2.1 to $77.0 \mathrm{~cm}^{3}$ in the invasive subgroup (mean, $12.1 \mathrm{~cm}^{3}$ ) and from 0.5 to $10.2 \mathrm{~cm}^{3}$ (mean $5.2 \mathrm{~cm}^{3}$ ) in the non-invasive subgroup. Post-operative follow-up ranged from 2.5 to 10.5 years (mean 4 years) and was not significantly different between the groups $(P=0.07)$. During follow-up, 17 patients with invasive tumors had stable remnants, while 5 patients had recurrences (invasive in two cases) after a mean of 3.8 years. In the noninvasive subgroup, 15 patients had no remnant and 3 patients had stable remnants; there were no recurrences in this subgroup during a mean follow-up of 4.8 years.

\section{Differentially expressed genes}

Using BrB software, a fold change- and intensity-based filtering approach $(>1.5$-fold change and $P<0.001$ ) selected 3771 features from among the 44000 present on the 60-mer oligonucleotide microarray. 
Prediction class analysis showed that 346 genes discriminated between invasive and non-invasive NFPAs $(P<0.001) ; 233$ genes were up-regulated and 113 were down-regulated in invasive tumors (Supplementary Table 2, see section on supplementary data given at the end of this article). As expected, the expression pattern of invasive adenomas was highly homogeneous, whereas non-invasive tumors fell into two subgroups (Fig. 1): one with a pattern very similar to that of invasive adenomas and one with a more heterogeneous pattern. Some of the differentially regulated genes have known functions in cancer, cell cycling, and cell death (up-regulated: $B A X, B C L 2, B B C 3, C D C 2 L 2, C D K 3, H N R P U, F L T 3$, IGFBP5, MYO5A, LTBP4, ADAMTS7, MMP17, RASA4, RAB18, SKI, and $M A G$; down-regulated: DST, DICER1, CITED1, PRDX2, TFG, RAB1A, RAC1, and $P I K 3 C B$ ), cellular assembly, morphology, and motility (up-regulated: FLNA, OSBP, MYO5A, TPM3, and TPM4; down-regulated: MAPILC3B, $S N A P 25, H M G B 1$, and DST), transcription factor and gene expression regulation (up-regulated: NFE2L1,
HNRPU, HSP9OAAl, and PARP10; down-regulated: $C X A D R, S N X 3, S R P 9$, and $S O N$ ), and metabolism or other functions (up-regulated: $O G D H, O S B P, U C P 3$, TBXAS1, and GRIN1; down-regulated: SSTR1 and $U B E 2 L 1)$. To further analyze the biological significance of these genes, we used Ingenuity pathway analysis. This approach identified seven networks involving a majority of the genes listed above. Two networks involved IGFBP5.

\section{Quantitative gene expression analysis}

On the basis of Ingenuity networks and the degree of up- or down-regulation in invasive versus non-invasive tumors, expression of 35 genes was quantified by qRT-PCR, and overexpression of only four genes was confirmed, namely IGFBP5 $(P=0.02)$, MYO5A $(P=0.04)$ (Fig. 2), FLT3 $(P=0.01)$, and NFE2L1 $(P=0.02)$. However, only two of these genes, IGFBP5 $(P=0.03)$ and MYO5A $(P=0.03)$, were confirmed to be overexpressed in an independent series of 19 gonadotroph tumors (data not shown).

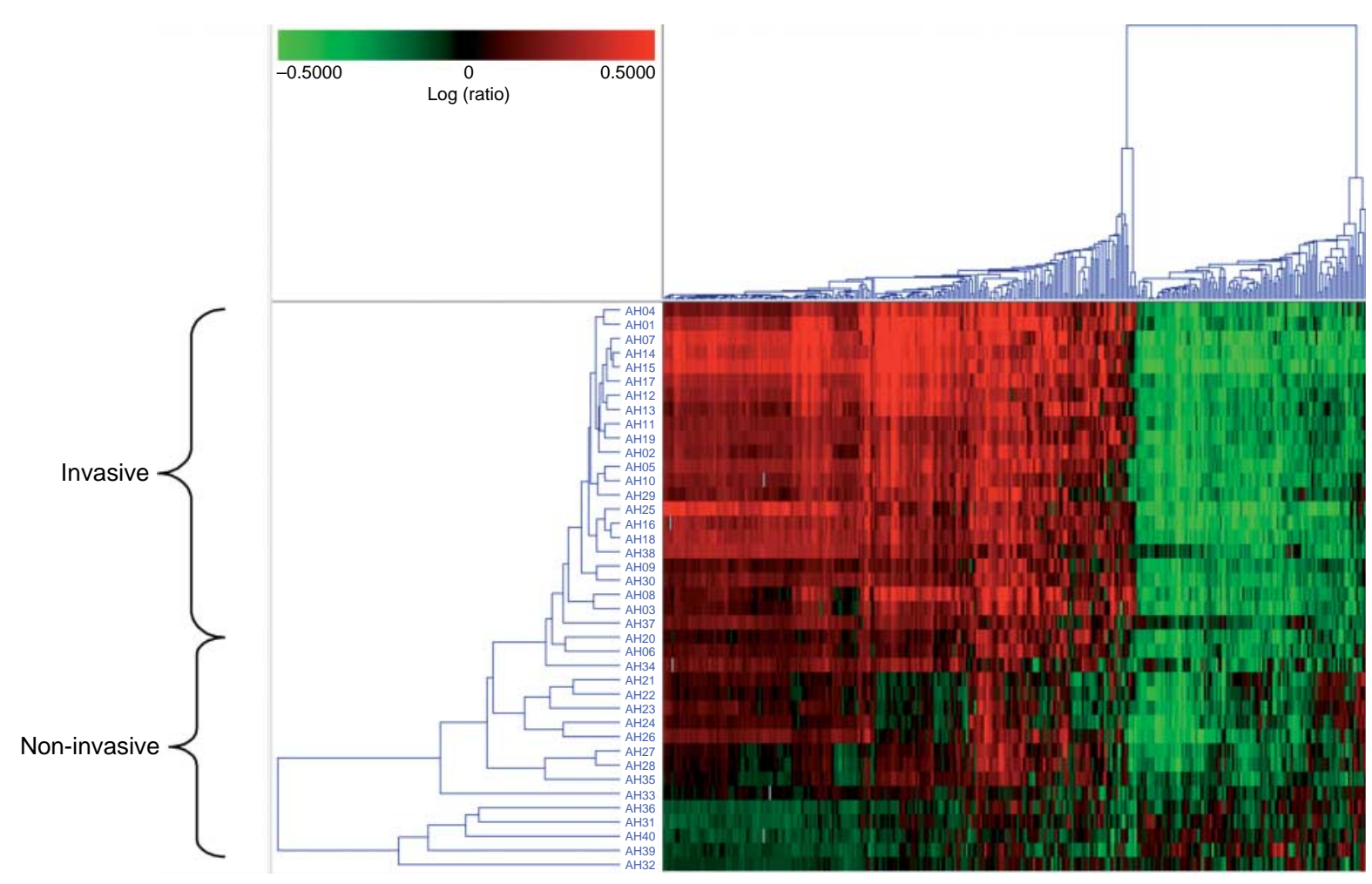

Figure 1 Cluster two-dimensional expression profile of the 346 genes differentially expressed between 22 invasive and 18 non-invasive non-functioning pituitary adenomas in microarray analysis. Red, up-regulated genes in invasive versus non-invasive tumors; green: down-regulated genes in invasive versus non-invasive tumors. The expression profile in the invasive subgroup was very homogeneous, contrary to the non-invasive subgroup. 

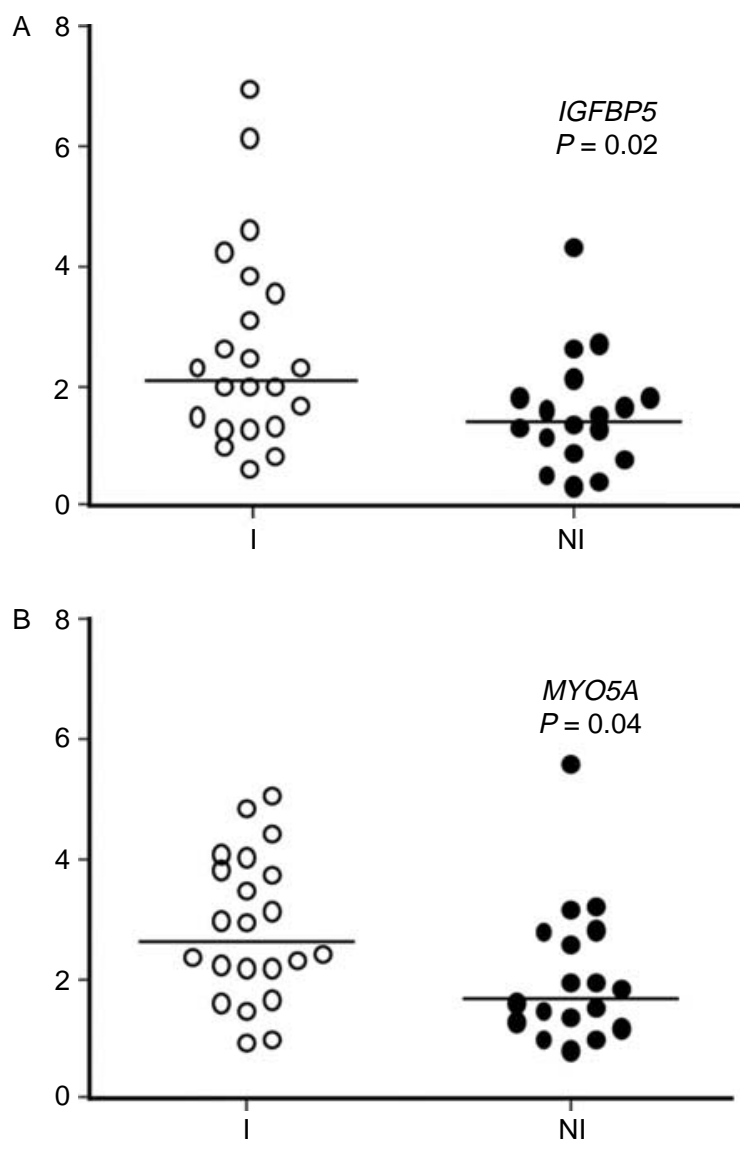

Figure 2 mRNA expression levels (arbitrary units) of IGFBP5 and MYO5A normalized to RPLPO in invasive, I (O), and noninvasive, $\mathrm{NI}(\mathbf{O})$, non-functioning pituitary adenomas. The horizontal line corresponds to the median value in each group.

\section{Protein expression}

Two gene products (MYO5A and IGFBP5) were selected for immunohistochemical studies. Positive immunostaining for MYO5A and IGFBP5 was not observed in normal pituitary tissue. In pituitary adenomas, MYO5A exhibited cytoplasmic immunostaining. Both the intensity of MYO5A immunostaining and the number of labeled cells were higher in invasive tumors than in non-invasive tumors: $70-100 \%$ of cells scored $(+)$ or $(++)$ in invasive tumors, while only $5-25 \%$ of cells scored $(-)$ or $(+/-)$ in non-invasive tumors (Fig. 3). IGFBP5 immunostaining (Fig. 3) was localized in the cell cytoplasm in both invasive and non-invasive tumors, with no clear difference in the number of stained cells or in staining intensity between the groups. Nuclear Ki67 immunostaining was present in only a minority of cells and, as expected, was not significantly different between the two groups (Supplementary Table 3, see section on supplementary data given at the end of this article). We found a good correlation between MYO5A and PTTG immunostaining but not between MYO5A and Ki67 immunostaining (Supplementary Figure 1, see section on supplementary data given at the end of this article).

\section{Discussion}

In the present study, using microarray analysis of 40 NFPAs, we were able to identify 346 genes which discriminated between invasive and non-invasive tumors, and to demonstrate that a set of two genes (MYO5A, IGFBP5) is overexpressed by qRT-PCR in invasive tumors. At the protein level, only the overexpression of MYO5A was confirmed.

Microarray technology has previously been used to evaluate gene expression during pituitary tumorigenesis, but most studies compared pituitary adenomas to normal pituitary tissues (Evans et al. 2001, Moreno et al. 2005, Morris et al. 2005, Farrell 2006, Gurlek et al. 2007, Shorts-Cary et al. 2007, Wierinckx et al. 2007 ) in order to identify genes associated with tumor pathogenesis. To gain insight into the mechanisms involved in pituitary adenoma invasiveness, we sought to identify genes that were differentially expressed in invasive and non-invasive forms. We found that a 346-gene signature discriminated between invasive and non-invasive tumors, some of these genes being involved in known biological functions such as cell cycling, cell death, cell morphology and motility, and gene expression regulation (transcription factors). After bioinformatic analysis of the molecular signature, among the selected 35 genes, only 4 of these genes (MYO5A, IGFBP5, FLT3, and NFE2L1) were overexpressed. After control in an independent series of NFPAs, MYO5A and IGFBP5 were found to be differentially expressed $(P<0.05)$ between the two tumor subgroups. Immunocytochemical analysis of protein expression showed that only MYO5A expression differed between the tumor subgroups, with stronger immunostaining in invasive tumors.

MYO5A is a member of the unconventional myosin family and shows broad tissue expression (Rodriguez \& Cheney 2002) principally in brain cells. Multiple functions have been assigned to this actin-dependent molecular motor, including the transport of melanosomes, smooth endoplasmic reticulum, recycling endosomes, neurotransmitter vesicles, mRNA (Reck-Peterson et al. 2000, Langford 2002, Salerno et al. 2008), and neuroendocrine vesicles (Rudolf et al. 2003). A role for MYO5A in tumor cell migration, invasion, and metastasis has recently been described (Du et al. 2007, Lan et al. 2010). Thus, our finding that MYO5A gene and protein expression is 


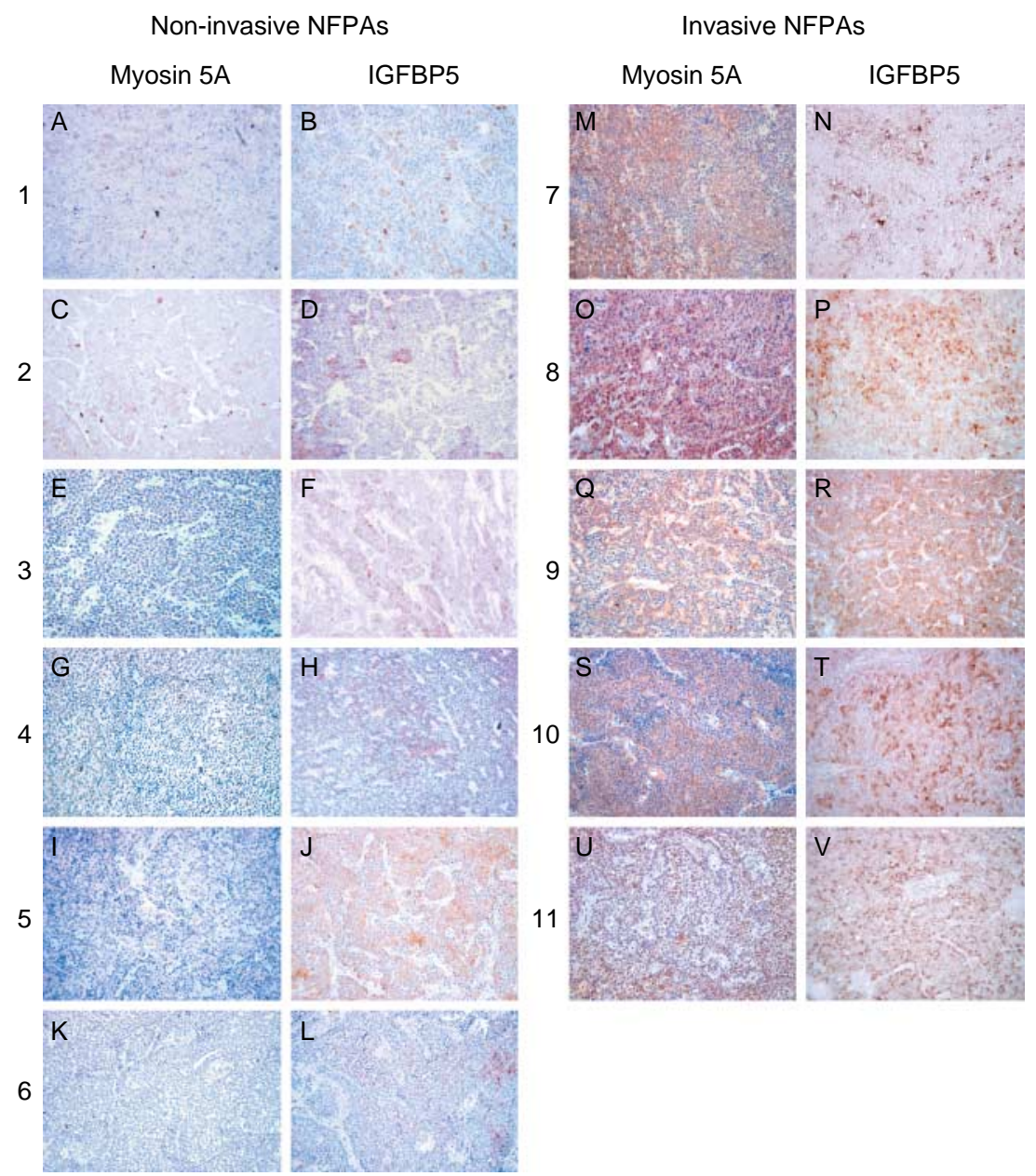

Figure 3 Expression of myosin 5A and IGFBP5 in six non-invasive NFPAs (numbered 1-6) and five invasive NFPAs (numbered 7-11) studied by immunohistochemistry. Myosin 5A is weakly to moderately expressed in non-invasive tumors; however the immunolabeling is limited to a reduced number of cells: in tumors $1(\mathrm{~A}), 2(\mathrm{C})$, and $5(\mathrm{I})$, the expression of this marker is found in 15, 25 , and $10 \%$ of cells respectively, and in $<5 \%$ of labeled cells $(E, I$, and $K)$ in the other tumors. IGFBP5 is moderately expressed in most non-invasive adenomas. The number of labeled cells is 10, 40, 30, 55, 70, and 30\% in tumors $1(B), 2(D), 3(F), 4(H), 5(J)$, and $6(\mathrm{~L})$ respectively. Myosin $5 \mathrm{~A}$ expression was moderate to strong in all invasive tumors. The immunolabeling was present in 80 , $75,70,100$, and $70 \%$ of the cells of adenomas $7(\mathrm{M}), 8(\mathrm{O}), 9(\mathrm{Q}), 10(\mathrm{~S})$, and $11(\mathrm{U})$ respectively. IGFBP5 expression was moderate to strong in all invasive adenomas. The immunolabeling was present in $50,40,100,50$ and $50 \%$ of the cells of adenomas $7(N), 8(P)$, $9(\mathrm{R}), 10(\mathrm{~T})$, and $11(\mathrm{~V})$ respectively.

higher in invasive than non-invasive NFPAs may have important implications, if confirmed in a larger series of NFPAs and also in other adenomas.

IGFBP5 was also overexpressed in our invasive tumors. The product of this gene has been shown to play a role in malignancy, and particularly in breast, ovary, and prostatic cancer (Hwa et al. 1997, Schneider et al. 2002, Johnson et al. 2006, Wang et al. 2006a,b, 2008, Nishino et al. 2008). However, IGFBP5 protein expression did not differ between invasive and noninvasive NFPAs. This could have several explanations including an extracellular secretion of IGFBP5, a posttranslational modification or a degradation of the protein.
Overall, the difference in gene expression between invasive and non-invasive tumors is not particularly striking. This is not unexpected, however, when comparing two grades of tumoral tissue, contrary to comparisons of tumoral and normal tissue. Interestingly, microarray analysis showed that invasive tumors had a very homogeneous gene expression profile (Fig. 1), contrary to non-invasive tumors. Some of the latter displayed an expression profile resembling the invasive expression profile, suggesting that they might be 'pre-invasive' or carry an increased risk of recurrence. A subsequent tumor outcome will be particularly informative. 
We cannot exclude that the 11-year difference in mean age of the patients with invasive tumors and noninvasive tumors has any impact on the data from microarray analysis as well as the validation by qRT-PCR and immunohistochemistry: the influence of age in expression of some genes or proteins in pituitary tumors has not been previously studied.

Our definition of invasive pituitary tumors was based on preoperating imaging studies, gross intraoperative observation, and post-operative histopathology. Some investigators claim that the definition of invasion requires histological evidence of dural invasion, but this is not routinely obtained in most centers and it has no long-term significance (Meij et al. 2002). The 2004 WHO classification (Al-Shraim \& Asa 2006) introduced the term 'atypical adenoma' for tumors with metastatic potential, based on prognostic markers such as the number of mitoses and Ki67 and p53 immunostaining, but the relationship of these markers with invasiveness is less clear (Asa 2008, Salehi et al. 2009). In our series, Ki67 immunostaining was similar in invasive and non-invasive NFPAs, but the predictiveness of the Ki67 labeling index for aggressive behavior is greater in functioning pituitary adenomas (including prolactinomas) than in NFPAs (Gurlek et al. 2007). Moreover, we have previously shown that the Ki67 labeling index is more reliable for predicting the recurrence of pituitary tumors (Filippella et al. 2006).

$P T T G$ and MMP9 were also up-regulated in the invasive tumors, as measured by qRT-PCR (data not shown), in keeping with previous findings (Turner et al. 2000, Trouillas et al. 2003, Filippella et al. 2006, Gong et al. 2008, Hussaini et al. 2007, Wierinckx et al. 2007). At the protein level, PTTG staining was stronger in invasive tissues and displayed a good correlation with that of MYO5A. By contrast with a previous report (Hussaini et al. 2007), MMP9 immunostaining was not different between the two groups.

In conclusion, microarray analysis of a large series of 40 NFPAs identified a molecular signature designating 'grossly' invasive tumors by comparison with noninvasive tumors. The product of one of these genes, MYO5A protein, may be a useful marker of invasiveness. The role of these genes in the invasion process of some pituitary adenomas - not only NFPAs but also other types - remains to be determined, along with their potential as predictive biomarkers of recurrence.

\section{Data availability}

The microarray data gathered in this study have been submited to the Array Express data repository at the European Bioinformatics Institute (http://www.ebi. ac.uk/arrayexpress/) with the accession number E-TABM-899.

\section{Supplementary data}

This is linked to the online version of the paper at http://dx. doi.org/10.1677/ERC-10-0018.

\section{Declaration of interest}

The authors declare that there is no conflict of interest that could be perceived as prejudicing the impartiality of the research reported.

\section{Funding}

This work was supported by a grant from the French Ministry of Health (Programme Hospitalier de Recherche Clinique Ile de France No. A0R03 052) and a grant of doctoral fellowship from Pfizer for F.A.

\section{Acknowledgements}

The authors thank $\mathrm{J}$ Bertherat and $\mathrm{X}$ Bertagna for providing information about some of their patients included in this study.

\section{References}

Al-Shraim M \& Asa SL 2006 The 2004 World Health Organization classification of pituitary tumors: what is new? Acta Neuropathologica 111 1-7.

Asa S 2008 Practical pituitary pathology: what does the pathologist need to know? Archives of Pathology \& Laboratory Medicine 132 1231-1240.

Asa SL, Bamberger AM, Cao B, Wong M, Parker KL \& Ezzat S 1996 The transcription activator steroidogenic factor-1 is preferentially expressed in the human pituitary gonadotroph. Journal of Clinical Endocrinology and Metabolism 81 2165-2170.

Bahar A, Simpson DJ, Cutty SJ, Bicknell JE, Hoban PR, Holley S, Mourtada-Maarabouni M, Williams GT, Clayton RN \& Farrell WE 2004 Isolation and characterization of a novel pituitary tumor apoptosis gene. Molecular Endocrinology 18 1827-1839.

Du YC, Lewis BC, Hanahan D \& Varmus H 2007 Assessing tumor progression factors by somatic gene transfer into a mouse model: Bcl-xL promotes islet tumor cell invasion. PLoS Biology 5 e276.

Dudoit S, Fridlyand F \& Speed T 2002 Comparison of discrimination methods for classification of tumors using DNA microarrays. Journal of the American Statistical Association 97 77-87.

Emery MN, Leontiou C, Bonner SE, Merulli C, Nanzer AM, Musat M, Galloway M, Powell M, Nikookam K, Korbonits M et al. 2006 PPAR-gamma expression in 
pituitary tumours and the functional activity of the glitazones: evidence that any anti-proliferative effect of the glitazones is independent of the PPAR-gamma receptor. Clinical Endocrinology 65 389-395.

Evans CO, Young AN, Brown MR, Brat DJ, Parks JS, Neish AS \& Oyesiku NM 2001 Novel patterns of gene expression in pituitary adenomas identified by complementary deoxyribonucleic acid microarrays and quantitative reverse transcription-polymerase chain reaction. Journal of Clinical Endocrinology and Metabolism 86 3097-3107.

Evans CO, Reddy P, Brat DJ, O’Neill EB, Craige B, Stevens VL \& Oyesiku NM 2003 Differential expression of folate receptor in pituitary adenomas. Cancer Research $\mathbf{6 3}$ 4218-4224.

Ezzat S, Smyth HS, Ramyar L \& Asa SL 1995 Heterogenous in vivo and in vitro expression of basic fibroblast growth factor by human pituitary adenomas. Journal of Clinical Endocrinology and Metabolism 80 878-884.

Ezzat S, Zheng L, Zhu XF, Wu GE \& Asa SL 2002 Targeted expression of a human pituitary tumor-derived isoform of FGF receptor-4 recapitulates pituitary tumorigenesis. Journal of Clinical Investigation 109 69-78.

Ezzat S, Asa SL, Couldwell WT, Barr CE, Dodge WE, Vance ML \& McCutcheon IE 2004 The prevalence of pituitary adenomas: a systematic review. Cancer 101 613-619.

Farrell WE 2006 Pituitary tumours: findings from whole genome analyses. Endocrine-Related Cancer 13 707-716.

Filippella M, Galland F, Kujas M, Young J, Faggiano A, Lombardi G, Colao A, Meduri G \& Chanson P 2006 Pituitary tumour transforming gene (PTTG) expression correlates with the proliferative activity and recurrence status of pituitary adenomas: a clinical and immunohistochemical study. Clinical Endocrinology 65 536-543.

Gong JZ, Zhao Y, Abdel-Fattah R, Amos S, Xiao A, Lopes MBS, Hussaini IM \& Laws ER 2008 Matrix metalloprotease-9, a potential biological marker in invasive pituitary adenomas. Pituitary 11 37-48.

Gurlek A, Karavitaki N, Ansorge O \& Wass JA 2007 What are the markers of aggressiveness in prolactinomas? Changes in cell biology, extracellular matrix components, angiogenesis and genetics European Journal of Endocrinology 156 143-153.

Hardy J 1979 Transphenoidal microsurgical treatment of pituitary tumours. In Recent Advances in the Diagnosis and Treatment of Pituitary Tumours, pp 375-388. Ed J Linfoot. New York, USA: Raven Press.

Heaney AP, Fernando M \& Melmed S 2003 PPAR-gamma receptor ligands: novel therapy for pituitary adenomas. Journal of Clinical Investigation 111 1381-1388.

Hussaini IM, Trotter C, Zhao Y, Abdel-Fattah R, Amos S, Xiao A, Agi CU, Redpath GT, Fang Z, Leung GK et al. 2007 Matrix metalloproteinase-9 is differentially expressed in nonfunctioning invasive and noninvasive pituitary adenomas and increases invasion in human pituitary adenoma cell line. American Journal of Pathology 170 356-365.
Hwa V, Oh Y \& Rosenfeld RG 1997 Insulin-like growth factor binding protein-3 and -5 are regulated by transforming growth factor-beta and retinoic acid in the human prostate adenocarcinoma cell line PC-3. Endocrine 6 235-242.

Johnson SK, Dennis RA, Barone GW, Lamps LW \& Haun RS 2006 Differential expression of insulin-like growth factor binding protein-5 in pancreatic adenocarcinomas: identification using DNA microarray. Molecular Carcinogenesis 45 814-827.

Knapen D, Vergauwen L, Laukens K \& Blust R 2009 Best practices for hybridization design in two-colour microarray analysis. Trends in Biotechnology 27 406-414.

Korbonits M, Chahal HS, Kaltsas G, Jordan S, Urmanova Y, Khalimova Z, Harris PE, Farrell WE, Claret FX \& Grossman AB 2002 Expression of phosphorylated p27(Kip1) protein and Jun activation domain-binding protein 1 in human pituitary tumors. Journal of Clinical Endocrinology and Metabolism 87 2635-2643.

Lan L, Han H, Zuo H, Chen Z, Du Y, Zhao W, Gu J \& Zhang Z 2010 Upregulation of myosin Va by snail is involved in cancer cell migration and metastasis. International Journal of Cancer 126 53-64.

Langford GM 2002 Myosin-V, a versatile motor for short-range vesicle transport. Traffic 3 859-865.

Leontiou CA, Gueorguiev M, van der Spuy J, Quinton R, Lolli F, Hassan S, Chahal HS, Igreja SC, Jordan S, Rowe J et al. 2008 The role of the aryl hydrocarbon receptor-interacting protein gene in familial and sporadic pituitary adenomas. Journal of Clinical Endocrinology and Metabolism 93 2390-2401.

Lundin P \& Pedersen F 1992 Volume of pituitary macroadenomas: assessment by MRI. Journal of Computer Assisted Tomography 16 519-528.

Meij BP, Lopes MB, Ellegala DB, Alden TD \& Laws ER Jr 2002 The long-term significance of microscopic dural invasion in 354 patients with pituitary adenomas treated with transsphenoidal surgery. Journal of Neurosurgery 96 195-208.

Melmed S 2003 Mechanisms for pituitary tumorigenesis: the plastic pituitary. Journal of Clinical Investigation 112 1603-1618.

Moreno CS, Evans CO, Zhan X, Okor M, Desiderio DM \& Oyesiku NM 2005 Novel molecular signaling and classification of human clinically nonfunctional pituitary adenomas identified by gene expression profiling and proteomic analyses. Cancer Research 65 10214-10222.

Morris DG, Musat M, Czirjak S, Hanzely Z, Lillington DM, Korbonits M \& Grossman AB 2005 Differential gene expression in pituitary adenomas by oligonucleotide array analysis. European Journal of Endocrinology 153 143-151.

Nishino R, Honda M, Yamashita T, Takatori H, Minato H, Zen Y, Sasaki M, Takamura H, Horimoto K, Ohta T et al. 2008 Identification of novel candidate tumour marker genes for intrahepatic cholangiocarcinoma. Journal of Hepatology 49 207-216. 
Pagotto U, Arzberger T, Theodoropoulou M, Grubler Y, Pantaloni C, Saeger W, Losa M, Journot L, Stalla GK \& Spengler D 2000 The expression of the antiproliferative gene ZAC is lost or highly reduced in nonfunctioning pituitary adenomas. Cancer Research 60 6794-6799.

Qian ZR, Sano T, Asa SL, Yamada S, Horiguchi H, Tashiro T, Li CC, Hirokawa M, Kovacs K \& Ezzat S 2004 Cytoplasmic expression of fibroblast growth factor receptor-4 in human pituitary adenomas: relation to tumor type, size, proliferation, and invasiveness. Journal of Clinical Endocrinology and Metabolism 89 1904-1911.

Radmacher M, McShane L \& Simon R 2002 A paradigm for class prediction using gene expression profiles. Journal of Computational Biology 9 505-511.

Ramaswamy S, Tamayo P, Rifkin R, Mukherjee S, Yeang $\mathrm{CH}$, Angelo M, Ladd C, Reich M, Latulippe E, Mesirov JP et al. 2001 Multiclass cancer diagnosis using tumor gene expression signatures. PNAS 98 15149-15154.

Raslova H, Kauffmann A, Sekkai D, Ripoche H, Larbret F, Robert T, Le Roux DT, Kroemer G, Debili N, Dessen P et al. 2007 Interrelation between polyploidization and megakaryocyte differentiation: a gene profiling approach. Blood 109 3225-3234.

Reck-Peterson SL, Provance DW Jr, Mooseker MS \& Mercer JA 2000 Class V myosins. Biochimica et Biophysica Acta $149636-51$.

Rodriguez OC \& Cheney RE 2002 Human myosin-Vc is a novel class $\mathrm{V}$ myosin expressed in epithelial cells. Journal of Cell Science 115 991-1004.

Rudolf R, Kogel T, Kuznetsov SA, Salm T, Schlicker O, Hellwig A, Hammer JA III \& Gerdes HH 2003 Myosin Va facilitates the distribution of secretory granules in the F-actin rich cortex of PC12 cells. Journal of Cell Science 116 1339-1348.

Salehi F, Kovacs K, Scheithauer BW, Lloyd RV \& Cusimano M 2008 Pituitary tumor-transforming gene in endocrine and other neoplasms: a review and update. EndocrineRelated Cancer 15 721-743.

Salehi F, Agur A, Scheithauer BW, Kovacs K, Lloyd RV \& Cusimano M $2009 \mathrm{Ki}-67$ in pituitary neoplasms: a review - part I. Neurosurgery 65 429-437.

Salerno VP, Calliari A, Provance DW Jr, Sotelo-Silveira JR, Sotelo JR \& Mercer JA 2008 Myosin-Va mediates RNA distribution in primary fibroblasts from multiple organs. Cell Motility and the Cytoskeleton 65 422-433.

Schneider MR, Wolf E, Hoeflich A \& Lahm H 2002 IGF-binding protein-5: flexible player in the IGF system and effector on its own. Journal of Endocrinology 172 423-440.

Shorts-Cary L, Xu M, Ertel J, Kleinschmidt-Demasters BK, Lillehei K, Matsuoka I, Nielsen-Preiss S \& Wierman ME 2007 Bone morphogenetic protein and retinoic acidinducible neural specific protein-3 is expressed in gonadotrope cell pituitary adenomas and induces proliferation, migration, and invasion. Endocrinology 148 967-975.
Simon R, Radmacher MD, Dobbin K \& McShane LM 2003 Pitfalls in the use of DNA microarray data for diagnostic and prognostic classification. Journal of the National Cancer Institute 95 14-18.

Simpson DJ, Clayton RN \& Farrell WE 2002 Preferential loss of death associated protein kinase expression in invasive pituitary tumours is associated with either $\mathrm{CpG}$ island methylation or homozygous deletion. Oncogene 21 1217-1224.

Trouillas J, Daniel L, Guigard MP, Tong S, Gouvernet J, Jouanneau E, Jan M, Perrin G, Fischer G, Tabarin A et al. 2003 Polysialylated neural cell adhesion molecules expressed in human pituitary tumors and related to extrasellar invasion. Journal of Neurosurgery $\mathbf{9 8}$ 1084-1093.

Turner HE, Nagy Z, Esiri MM, Harris AL \& Wass JA 2000 Role of matrix metalloproteinase 9 in pituitary tumor behavior. Journal of Clinical Endocrinology and Metabolism 85 2931-2935.

Wang H, Rosen DG, Wang H, Fuller GN, Zhang W \& Liu J $2006 a$ Insulin-like growth factor-binding protein 2 and 5 are differentially regulated in ovarian cancer of different histologic types. Modern Pathology 19 1149-1156.

Wang H, Wang H, Zhang W \& Fuller GN $2006 b$ Overexpression of IGFBP5, but not IGFBP3, correlates with the histologic grade of human diffuse glioma: a tissue microarray and immunohistochemical study. Technology in Cancer Research \& Treatment 5 195-199.

Wang H, Arun BK, Wang H, Fuller GN, Zhang W, Middleton LP \& Sahin AA 2008 IGFBP2 and IGFBP5 overexpression correlates with the lymph node metastasis in T1 breast carcinomas. Breast Journal 14 261-267.

Wierinckx A, Auger C, Devauchelle P, Reynaud A, Chevallier P, Jan M, Perrin G, Fevre-Montange M, Rey C, Figarella-Branger D et al. 2007 A diagnostic marker set for invasion, proliferation, and aggressiveness of prolactin pituitary tumors. Endocrine-Related Cancer 14 887-900.

Wright GW \& Simon RM 2003 A random variance model for detection of differential gene expression in small microarray experiments. Bioinformatics 19 2448-2455.

Zhang X, Horwitz GA, Heaney AP, Nakashima M, Prezant TR, Bronstein MD \& Melmed S 1999 Pituitary tumor transforming gene (PTTG) expression in pituitary adenomas. Journal of Clinical Endocrinology and Metabolism 84 761-767.

Zhang X, Sun H, Danila DC, Johnson SR, Zhou Y, Swearingen B \& Klibanski A 2002 Loss of expression of GADD45 gamma, a growth inhibitory gene, in human pituitary adenomas: implications for tumorigenesis. Journal of Clinical Endocrinology and Metabolism 87 1262-1267.

Zhang X, Zhou Y, Mehta KR, Danila DC, Scolavino S, Johnson SR \& Klibanski A 2003 A pituitary-derived MEG3 isoform functions as a growth suppressor in tumor cells. Journal of Clinical Endocrinology and Metabolism 88 5119-5126. 